\title{
Indian Magic Manuals. Man in the World of Violence
}

\author{
Artur KARP
}

\begin{abstract}
In present-day India magic is not a theoretical construct. Practiced as witchcraft, it has its self-appointed officials and procedures. It is also manifest, most tellingly, in the easy availability of the cheap editions of what may, with some reservations, be termed as manuals of magic. The activation of religiosity characteristic of Indian tribal communities, to which most of the currently favorite magical rituals can be traced, is a not-so unique answer to the violence inherent in the social, economic, and political life of the nation. The methods of con- trolling complex reality presented in those manuals revive traditional cultural patterns, and may thus restore feelings of participation and justified agency to their users.
\end{abstract}

Keywords: tribal groups, violence, untouchability, caste, magic, Sanskritisation

Artur KARP MA indologist; retired Senior Lecturer at South Asian Studies Department, University of Warsaw. In UW (1969-2007) classes in Sanskrit and Pali, and lectures on ancient cultures of India, history of Buddhism. 1973-77 lecturer in Polish at Modern European Languages Dept., University of Delhi. Author of cross-sectional entries on Indian mythologies and religions for "Religia. Encyklopedia PWN" (vol. I-X, Warszawa 2001-2003). Till 2018 courses on Indian caste system and untouchability at Historical Anthropology Dept., UW. At Collegium Civitas lectures: "Indian Civilization" and "Buddhism in the World of Power and Politics". Translations of Buddhist texts from the Pali language.

E-MAIL: karp@uw.edu.pl 
1 Migrations of the politically and economically weaker segments of India's population to the already developed, rural and urban parts of the country is a process of long duration. Historically, it resulted in the adopting of the India-specific division of work, based on the idea of extreme inequality, that is untouchability, ${ }^{1}$ and - finally - in the creation of local caste systems. The process continues, and in some areas of the country, takes dramatic forms. The Indian government currently seizes large areas of the country and utilises them for the development of road and railway networks, military bases and training grounds, opencast mines, and large-scale industrial installations. ${ }^{2}$ This practice leads to displacement and, finally, to the disintegration of numerous weaker tribal communities. ${ }^{3}$ As pointed out by Dhru in her 2010 analysis, "The effects of displacement spill over to generations in many ways, such as loss of traditional means of employment, change of environment, disrupted community life and relationships, marginalisation, a profound psychological trauma and more."

Also in India, the shift from local to regional identities, which accompanies displacement, would typically result in the lowering of the barriers of language and religion. The most characteristic sign of these homogenising, generalising transitions, as aptly captivated in Kłoskowska's 2006 book, is the ongoing creation of regional and trans-regional variants of popular culture. In India, these new patterns creatively employ all available traditional media and the suitable forms of expression (among them storytelling, poetry, painting, sculpture, music). They also reach for such languages that may serve as lingua franca - such as hindustāni in the north of the subcontinent, with its standard colloquialisms and simplified grammar, far from Sanskritic influences in its vocabulary, but enriched by numerous Arabic-Persian borrowings.

1 See L. Dumont, Homo Hierarchicus, pp. 52-53, 134-135; concisely A. Karp, Niedotykalni, pp. $283-285$.

2 On the problems caused by the Government's acquisition of land for development projects (such as - among the already completed - Sagar Sarowar Dam, Indra Sagar Dam, Koraba Coal Mines) see H. L. Harit, Tribal Areas and Administration, pp. 49-54; S. Mehta, Tribal Situation in India. Encounters with Empiricism, pp. 55-66.

3 Indian tribal/aboriginal groups are collectively named adivāsi - "original inhabitants"; they make up $8.6 \%$ of India's population, that is, as of 2019 (UN est.), over 117 million people, see: http://www.worldometers.info/world-population/indiapopulation. For the list of the constitutionally recognized tribes see: https:// www.wikiwand.com/en/List_of_Scheduled_Tribes_in_India. 
2 The term homogenising transition carries in itself the idea of original differentiation. When introduced, it brings to the fore the question of what in the sphere of Indian culture is central and what peripheral. A preliminary inquiry into the available material seems to indicate the need to break free from the continuing practices of reducing the role of magical thought, and the images of the world it generates in the process of creating an ideal model of Indian culture, in its historically variable but invariably socially privileged forms.

Indian anthropology defines transition in two ways; both favour preserving the so far standard presentation of tradition as divided into two unbalanced segments - the sphere of "high," described and promoted in thousands of publications, and "low" culture.

In his 1971 Primitive Religions in India, Henry H. Presler has introduced the term "primitive type of religiosity." 4 While presenting the main features (such as ecstatic rituals, soothsaying, exorcism) of a diverse cultural complex, including belief systems of tribal communities and low-caste groups, known in the modern Indian bureaucratic terminology as scheduled tribes and scheduled castes, he considered them not fully developed.

A similar function is fulfilled by the concept of "culture survivals/relics"5 developed within western anthropology. It allows for the terminological separation of certain worrisome, indefinable elements, strongly rejected, and yet continually penetrating the sphere of "high" culture, with its grand religious ideas and sublime tools for their expression.

The concept of "great" and "little" tradition has been taken over by Indian social scientists from Robert Redfield's 1966 book. ${ }^{6}$ Following him, the forms of Indian culture referring to the elite, Sanskritic pattern, were given the title of Great Tradition, and were ultimately popularised by Milton Singer, in his immensely influential 1972 book When a Great Tradition Modernizes.

4 H. H. Presler, Primitive Religions of India, pp. 170-174, 218-239, 256-272; Presler is also the author of the - often quoted - thesis on the actualisation of contents carried by this type of religiosity in the face of modernisation processes. See also: W. Crooke, Religion and Folklore of Northern India; L. S. S. O’Malley, Popular Hinduism; G. W. Briggs, The Chamārs; N. N. Bhattacharya, Ancient Indian Rituals and their Social Contexts.

5 See E. Sapir, American Indians, pp. 409-410.

6 See R. Redfield, Peasant Society and Culture, p. 70: "In a civilization there is a great tradition of the reflective few, and there is a little tradition of the largely unreflective many." 
3 The presentation of internal Indian disputes regarding the boundaries of Great Tradition ${ }^{7}$ goes beyond the scope of this paper. However, let it be recalled that the fulfillment of this naming initiative was not without political undertones. The definitive dissociation of the religious and philosophical Indian thought from the old world images and archaic beliefs they carry, took place only in the second half of the nineteenth century, under the influence of Western ideas of what the term "religion" means. The early authoritative proponents of the renewal of Hinduism, Ram Mohan Roy (1772-1833) and Dayanand Saraswati (1824-1883), have opposed in their work the sphere of pure religion to the sphere of blind, superstitious faith (h[indi]. andhā viśvās), with its widow self-immolation (satī) rule, caste rigidity, polygamy and child marriages. It is ultimately thanks to the efforts of British colonial politicians that an arbitrarily selected segment of Hinduism was offered as, and finally obtained the status of, a world religion, ${ }^{8}$ ready for a peer-to-peer dialogue with Christianity and Islam.

The remaining segments, regardless of their role played in the country's religious life and of the language used in them, were to become a subject of interest, not so much for formal religious studies, but more for ethnography, ethnology, and anthropology of culture. Although numerous publications appeared devoted to selected aspects of the Indian tribal/low caste medical lore, ${ }^{9}$ valued exceptionally high for its lists and descriptions of traditional herbal remedies, there are no monographs devoted to the attempts of one of the "Little traditions" to modernise. Do any of them possess an organisational structure that would enable them to embark on their path to modernization ${ }^{10}$

7 See T. K. N. Unnithan et al., Towards a Sociology of Culture in India - where an early attempt at presenting the topic; a broad analysis of the political-religious themes present in the endeavours aiming at the modernisation of the Indian "Great Tradition" in M. Singer, When a Great Tradition Modernizes: An Anthropological Approach to Indian Civilization. See also Y. Singh, Modernization of Indian Tradition. A Systematic Study of Social Change.

8 On the process see D. Lorenzen, Who Invented Hinduism.

9 Such as (selected to represent hundreds of publications): S. Kakar, Shamans, Mystics and Doctors. A Psychological Inquiry into India and its Healing Traditions; V. Sujatha, Food: The Immanent Cause from Outside - Medical Lore on Food and Health in Village Tamilnadu; P. Froerer, Health, Biomedicine and the RSS; R. Barrett, Aghor Medicine, Pollution, Death, and Healing in in Northern India; T. Chakravarty, Medicalisation of Mental Disorder: Shifting Epistemologies and Beyond.

${ }^{10}$ During the decades after independence, seven tribe-inhabited territories became states within the Republic of India. These included Nagaland (1963), Manipur (1972), Meghalaya 
Redfield's suggestion that the importance of tradition may be ascertained solely depending on the ability of its bearers to reason was finally rejected. From the circles of human rights activists, voices of protest flow against the deep-rooted conviction, according to which, all forms of folk and tribal culture not fitting in the canon of the Great Tradition are merely signs of locality and cultural inferiority. ${ }^{11}$ These forms, however, continue to be referred to as Little Traditions - and that regardless of the element of rating suggested by the opposition of the adjectives "great" and "little."

4 Already in its early stages of development, Indian literature creates images of aliens using spells aiming to destroy of human communities. The term "Indra's net" (s[anskrit]. indrajāla) - that is sorcery - occurs for the first time in the Atharvaveda, the youngest of the four Vedas, recognised for the sake of its contents as the first known collection of magical formulas and spells. ${ }^{12}$

Figures of demonic individuals encountered on undeveloped - from the perspective of the state - spaces, and of individuals using magic for personal purposes while operating from within the class-caste system (s. varnajāti), appear already in the literature of the Epic period, that is from about the $4^{\text {th }}$ century BC.

The Indian culture of word demands that all new spheres of experience be named and ordered. Considering that, the lack of even a working definition of magic is unusual. It can be produced, but only in the most general terms, from what appears in the classical concepts of civilised principles of conduct. ${ }^{13}$

(1972), Arunachal Pradesh (1987), Mizoram (1987), and, finally, Chhattisgarh and Jharkhand, both formed in 2000 . However, these state-forming initiatives have not resulted in the appearance of new political-national entities, with their independent forms of "modernised traditions". On the process, see J. W. Elder, Scheduled Tribes, [in:] Encyclopedia of India, [www 01] (access: 04.06.2019).

${ }^{11}$ See D. Mosse, Caste and development. Contemporary perspectives on a structure of discrimination and advantage.

${ }^{12}$ AV VIII.8.8:

ayaṃ loko jālamāsīcchakrasya mahato mahān|

tenāhamindrajālenāmūmstamasābhidadhāmi sarvān \|

William Dwight Whitney (1827-1894):

"This great world was the net of the great mighty one; by that net of Indra do I encircle all yon men with darkness."

13 See P. Olivelle, Dharmasūtras. The Law Codes of Āpastamba, Gautama, Baudhāyana, and Vāsiștha; in a newer exposition: Idem, King, Governance, and Law in Ancient India. Kautilya's Arthaśāstra. 
In short: in contrast to religion, which combines what is both personal and communal, magic is any alien rite, performed against the needs and the rules of communal life, to satisfy purely individual aspirations.

5 Manuscripts containing magic spells and diagrams appeared in higher numbers as early as the first half of the first millennium $\mathrm{AD},{ }^{14}$ as a sort of mental support for those initiated in the field of magic, conceived as formal knowledge, often as skill. ${ }^{15}$ Although they did not include any detailed commentary on how to pronounce spells (distribution of accents, the tempo of delivery) and on plotting diagrams, caution was advised, as they were not allowed to fall into unauthorised hands.

Popular in the 19th-century and originally handwritten, The Compendium of the Knowledge of the Net of Indra (Indrajālavidyāsamgraha) is the collection of Sanskrit texts referring to the Tantric tradition. ${ }^{16}$ The date of its creation has not yet been determined. The texts depict ways of changing reality through the use of magical procedures. Initial verses of the The Book of the Indra's Net, the first text in the collection, attempt to convince readers of the importance of the tradition conveyed to them:

athātah sampravakșyāmi cendrajālamanuttamam | vyādhidāridryaharaṇaṁ jarāmrtyuvināśanam $|\mathbf{1}|$ I am announcing this here "Indra's Net," unparalleled, removing disease and poverty, annihilating old age, and death.

na teșām jāyate siddhirgotre kșetre grhe'pi vā indrajālam na jānāti sa kruddhaḥ kim kariṣyati $\left.\right|_{3} \mid$ No success for him, within [his] kin, in [his] fields, at home Not knowing the "Indra's Net," what could one achieve in anger?

${ }^{14}$ The oldest known, written down on birch bark document of this type comes from the epoch of the Guptas (IV-VI c. AD); it contains two last treatises in the so-called Bower's Manuscript. See R. A. F. Hoernle, The Bower Manuscript.

${ }^{15}$ The analysis of the language of magic and of the magical act as a spectacle - see S. J. Tambiah, Magic, Science and Religion and the Scope of Rationality; elaboration of the topic in P. A. Moro, Witchcraft, Sorcery, and Magic, [in:] The International Encyclopedia of Anthropo$\log y$, [www 04] (access: 9.06.2019).

${ }^{16}$ Published at Vidyasagar's Sons, Calcutta 1915; the collection is comprised of five texts: The Book of the Indra's Net (Indrajālaśāstram), The fewel of Love (Kāmaratnam), The Dattatreya's Loom (Dattātreyatantram), The Oil Lamp of the Six Actions (Satkarmadīpikā), The [Fragrant] Armpit of Accomplished Nagarjuna (Siddhanāgārijunakakșapuțam); see T. Goudriaan, Hindu Tantric Literature in Sanskrit, p. 122. 
yathā nadīnadāḥ sarve sāgare samupāgatāḥ| tathā sarvāṇi śāstrāṇi indrajālasthitāni ca $|6|$ Like all rivers, [be they] female or male, meet in the ocean, just so all [holy] treatises may be found in the "Indra's Net."

taptānāñca yathā bhānuh śìtālānam yathā śaśi | gambhīrānāim yathā sindhurjālendrañca tathā priye $|7|$

As for the hot ones the Sun, as for the cool ones the Moon, as for the deep ones the Indus, such is "Indra's Net."

tathā kim bahunoktena varnanena punah punah | jālendrasya samai் śāstrai் na bhūtam na bhavișyati $|8|$

Why, then, so many words, trying to explain it, again and again?

A book similar to the "Indra's Net" has never been

and shall not be.

6 Some magical techniques were referred to in exceptional situations, especially during moments of natural, elemental disasters that threatened the existence of entire communities, such as flood, drought and epidemics. Also, when other measures failed, in the face of personal crises caused by the not fully recognised psychosomatic factors.

While describing such situations, modern texts usually combine the functions of a sorcerer (h. ojha $)$ with a low (or vague) social status. Sorcerers and healers appearing in them usually hail from tribal communities or groups located at the bottom of the caste hierarchy. Their dark powers, possessed because of their "former ownership of this land," were appealed to in the face of threats. On other occasions, it was the very possession of such powers that could serve as the grounds for the accusations for practicing evil spells, an extreme form of antisocial behaviour, betraying the aspirations that are unjustified by ritual status.

The problem of the socially and culturally uncertain identity of such mythical personages is well illustrated by the story of Putana (pütanā). In its popular variants, Putana is a witch, the demonic murderess of children (s. bālaghātinī), personifying boundless hostility to the humankind; infant Krishna killed her by emptying her breasts of her venomous milk. ${ }^{17}$ It is worth mentioning, however, that her name may be interpreted as originat-

${ }^{17}$ For overviews of the story, see W. Doniger O'Flaherty, Women, Androgynes, and Other Mythical Beasts; S. Kakar, op. cit. 
ing not from one, but two adjectives (s. püta) possessing radically different meanings - as "pure" and "putrid." In one tradition, her name would mean "purity," in the other, more influential one - "putridity."

Both social categories - the untouchables and members of tribal communities living on the outskirts of caste societies ${ }^{18}$ - could (and still can, depending on the need) perform the role of aliens.

7 In India, the transfer of knowledge has always been subject to many restrictions. In any field, only those who had managed to pass through a series of initiation rites were given complete knowledge, and only they could pass it on. The dissemination of literacy and low-cost printing have introduced a significant correction to the traditional forms of conveying secret knowledge: the function of the initiator began to be fulfilled by books.

Magic manuals already appeared on the Indian book market at the end of the 19th century. However, only in the last half-century, new printing techniques (offset printing and digital composition) made it possible to publish them in cheap, large editions. At present, they are also sold by mail order and as $e$-books, by publishing houses specialising in the distribution of tabloid literature, guides for homemakers, agricultural calendars and self-tutorials. Their covers tempt prospective buyers with bright colours, images of greybearded sages, half-naked women, human skulls, and horned monsters, baring their fangs in wicked grins. ${ }^{19}$

8 The manuals are usually standard in their construction. The title page of The True Anciently Handwritten Net of Indra ${ }^{20}$ prompts the buyer to start reading it in the ritual manner prescribed for the initiation, that is - in the morning, before sunrise, while seated after bathing (to cleanse the body and spirit) on the sacred kuśa grass. ${ }^{21}$

${ }^{18}$ Formerly termed as "scheduled castes and tribes." Since the 1970 os collectively known by their own appellation as Dalits (h. dalit - "broken, oppressed"). On the reasons for and forms of the criminalisation of this segment of India's population (over 160 million), see H. Thiagaraj, Human Rights from the Dalit Perspective; S. Yengde, Free the Freedom: Where Untouchability is Locked Away in Prisons, "The Citizen is Helpful" (2017), [www 05] (access: 6.09.2019).

${ }^{19}$ Solely publications in Hindi were used for the purposes of this paper; similar to them are mass-printed also in the other languages of the subcontinent, such as Bengali or Tamil.

${ }^{20}$ Aslī prācīnhastalikhit purāṇā indrajāl, Dehāti Pustak Bhaṇdar ("The People’s Library”), Delhi, without date.

${ }^{21}$ Desmostachya bipinnata, a species of grass, used in various Indian religious traditions as a sacred plant; of extreme importance in the Vedic ritual. 
The preamble usually contains a warning formula: the publisher equates magic knowledge with a weapon that is neither good nor bad by itself, but can be used in the service of good or evil. It warns the reader about the risk of being exposed to dangers awaiting all those who would practice spells exclusively to satisfy their ambitions or to manifest their ill will towards others. The warning is often followed by a call to master this "ancient knowledge for achieving successes in life." One manual develops the concept of "life success," asking the reader: "How could you, who acquired this ancient book, miss anything? Money, wisdom, fame, offspring, victory over the enemy whatever you want, everything will come true.” The True Net, however, adds: "The modern man only reluctantly approaches any harder work; he would like to work so as not to get tired. There were times when people would go at midnight to cremation grounds, and there, giving themselves to hard and dangerous mortifications, "gained power over the spirits of the dead. And thanks to that, they performed great deeds ${ }^{22}$." Thousandfold thanks are to God that we were able to publish this book, already thought to be forever lost. We searched for it for many years and have spent thousands of rupees looking for it. We can finally present it to the reader - so that he can use it".

After the introduction, there follows a part presenting the significance of magical actions, their classification and symbolism of their main background components - the segments of time and elements of space.

The next, the second part, is a vast, more or less ordered catalog of spells, magical charts, and formulas spoken during the preparation of magical substances.

The third part does not appear in all manuals. Serving as a sui generis household guide, it provides recipes for cheap and effective removal of stains from various types of fabrics, suggests the methods for desalination of water, for mending broken pottery and porcelain, for cleaning of brass, copper, and plastic. Here, one can also find a set of a dozen or so typical "magic" arcade tricks to be used on social occasions.

9 The "theoretical" first part refers directly to Sanskrit tantric texts, such as the previously mentioned Compendium of the Knowledge of the Net of Indra. Following the textual tradition, also The Oil lamp ${ }^{23}$ included in this collection divides magical actions into six general types: ${ }^{24}$

${ }^{22}$ P. 17: h. “mrtak àtmāõo ko vaś mẽ karke barebare kām nikālte the.

${ }^{23}$ Pp. 180-264.

${ }^{24}$ A detailed description of the Six Acts: T. Goudriaan, S. Gupta, Māyā Divine and Human, pp. 251-412. 
śāntikaraṇam calming; pacification

vaśîkaraṇam subordinating; domination

stambhanam stopping; immobilization

vidveșanam dividing; separation

uccāțanam uprooting; exclusion

māranam killing; destruction

The order of these operations does not change. It is a fixed sequence, whose parts cannot be freely moved - they have already been sorted out, in order from the weakest and most gentle, to strong, hard, requiring the use of force, and even extreme violence. However, significant differences occur in the definitions of actions provided by the texts. Only their comparison allows us to state that the purpose of magic in its Indian variant is to control reality in three spheres - in the sphere of social relations, in the sphere of nature, animate and inanimate, and inside the human body.

The True Net of Indra gives the following definitions of the six actions:

"śântikaranam is an act by which one obtains peace from the spells, possession by demons and other harmful states;

vaśi karaṇam thanks to it, women, men, and other living beings are subordinated to each other;

stambhanam thanks to it, the movement of various living beings is stopped;

vidveșanam thanks to it, the mutual love and friendship of living beings are destroyed, mutual hatred is stirred up;

uccātanam thanks to it, man can be expelled from his village, city or country;

märanam thanks to it, the vital breath of beings is destroyed."

10 This division presupposes six additional activities:

pacification conforms to disturbing

domination - to liberating

immobilization - to starting up

separation - to connecting

exclusion - to establishing

destruction - to animating

The presence of these implied actions is the key to understanding the world of creators and users of the manuals. It allows them to get deeper into 
their ideas about reality. In addition to the acting subject and the object of the action, there appears another operating entity - a hidden rival with opposing intentions and plans.

Whoever conducts a magical game must always consider that he is not its only participant. Each action is only a contraction, a response to a situation created by someone else. In the world of these textbooks, nothing happens without reason, and there is no room for coincidence. The fate of people is determined not only by the law of retribution for acts committed in previous lives (s. karman) but also by the impact of powers set in motion by powerful enemies or allies, including their ancestors.

11 Those six pairs of magical actions respond adequately to the set of basic techniques used in the north-Indian "white," beneficent (h. jhār phũknā"sweeping over, blowing on") and "black," destructive magic (h. tonā urāna “casting (evil) spells").

The use of a positive or negative member of any pair depends on the specific situation. In the social sphere, an expulsion is a hostile act (regardless of its reasons), but it is a beneficial healing act if it aims to remove the harmful substance from the human or animal body. In both cases, analogous symbolic acts are recommended, namely - placing the removed element (in the first case it is a card with the name of the enemy inscribed in the corresponding diagram, in the second, the object extracted from a sick body) in a closed vessel and setting it afloat on the river. The same applies to the immobilizing (paralyzing) of an opponent and the arrest of premature foetal movement.

Regardless of the motivation of the acting person, texts attribute to particular actions the codes of colour, time of day, the season of the year, quarter, guardian deity, the animal, and place. Also, though not always - of the lunar days (s. tithi), smell, gesture, body position, flower, the skin of the animal on the seat.

pacification is accompanied by whiteness, dawn, winter, northeast

domination - by redness, morning, spring, north

immobilization - by yellowness, evening, cool season, east

separation - by scarlet, noon, hot season, south

exclusion - by grayness, afternoon, rainy season, northwest

destruction - by blackness, north, autumn, southeast

Classifications of this kind are not unusual for Indian literature. By combining a series of actions with appropriate codes, the list introduces the re- 
cipient into a complex sign system that allows one to read and adequately react to the hidden messages appearing in the surrounding reality. It also helps one to avoid situations in which, while being confident of acting on one's own, one might implement someone else's, alien strategies. ${ }^{25}$

12 The second part of the manuals is a somewhat free compilation of tantric and quasi-medical texts.

The final formulas of many spells appearing there, contain appeals to the cultural heroes of the Indian untouchables - to Nūnā Camārin, ${ }^{26}$ Ismail Jogî̀ ${ }^{27}$ and Rāī Dās. ${ }^{28}$ Some spells, as if to increase their power, interlace the Hindu with the Muslim magical formulas.

Most spells are short, condensed formulas, but there is no dearth of versified spells, with a high literary value. Spells are often accompanied by detailed instructions, especially for the preparation of recommended drugs and magical substances, for making symbolic images of enemies, and for constructing magical traps.

The manuals present a particular understanding of disease. According to them, it is a disruption of the natural balance of factors co-creating the body - caused by intentional action from the outside. Most diseases can, therefore, be considered as psychosomatic disorders resulting from magical attacks. The diseases enumerated in such texts also include states after bite of a mad dog, snake bites, scorpion stings - as well as toxic conditions caused by the consumption of alkaloids of plant origin.

The motif of transformation, occurring in a whole range of spells, points out belief in the possibility of transforming humans into animals, such as snakes, crows, vultures, jackals, tigers, monkeys.

${ }^{25}$ In the enumeration of cardinal directions so far unnoticed lack of "west" and "southwest". These zones are not linked with any magical action. Could they - as "empty" - serve to provide the sorcerer with a safe space, in case of hostile attack?

${ }^{26}$ Known also as Noṇā, Lūṇā, Loṇā. See D. G. White, The Alchemical Body: Siddha Traditions in Medieval India, pp. 298-300.

${ }^{27}$ Ismail Jogī - mythical personage of unclear Moslem-Hindu provenience. According to W. Crooke (op. cit.) appellation of the demon of severe diseases; nowadays appealed to by men in spells to overcome female sexual coldness.

${ }^{28}$ Patron saint of untouchable artisans processing animals skins (tanners, saddlers, cobblers); known also as Rāe Dās and Ravi Dās; the legendary shoemaker, breaking down the caste constraints - Brahmin born from the womb of an untouchable woman. History of his deeds was half a century ago given the form of the Sanskritic "ancient [tale]". See Makhandās, Śrī cãvara purāṇa, See also G. W. Briggs, op. cit., pp. 30, 207-212. 
13 Since magical practices often collide with the law and conventionally understood norms of social coexistence, the state is involved in combating them - using the police apparatus of repression ${ }^{29}$ and all modern media (press, radio, cinema, TV). The educational institutions and Neo-Hindu missionary sects have a similar agenda. They are supported by far-right groups propagating the "pure" pattern of the brahminic "Great Tradition" - such as the Vishwa Hindu Parishad (VHP) and the Rashtriya Swayamsevak Sangh (RSS). ${ }^{30}$

14 Building the atmosphere of social condemnation for the conduct that deviates from the norms sanctioned by the Great Tradition, in its subsequent forms, and the unification of the originally strongly diversified Indian patterns of religiosity, are two faces of a long-lasting, historical process of the recomposition of the Indian social and political scene. The Indian sociologist, Mysore Narasimhachar Srinivas, analysed and described it in his pioneering 1962 work; he also called it Sanskritisation.

In his view, sanskritisation is a specifically Indian form of acculturation. ${ }^{31}$ It is based on the shifting of topics and patterns of culture from a group possessing high social and ritual status (Brahmins) towards groups that aspire to reach such a status. The underlying mechanism enabling such movement was considered imitative: low-caste groups initially mimic prestigious brahminic customs, house rituals, community religious practices and adopt vegetarianism and abstinence - as a norm. In the final stage of sanskritisation (when cooperation with the Brahmin priest plays an important role), they remodel their ritual and pantheon, placing their deities among the manifestations of one of the great divinities of Hinduism. These processes, which have been going on for centuries, have now accelerated, mainly thanks to mass education and the influence of mass media. An essential role in this context is

${ }^{29}$ Extrajudicial actions, conducted by the police against women suspected of being witches, remain a problem in India. A group of deputies has recently moved in the Lower House of the Indian Parliament for the statutory introduction of laws and regulations making the practice of "witch hunting" illegal [http://164.100/47.4/BillsTexts/LSBillTexts/AsIntroduced/4572LS.pdf]; see R. Lakhanpal, The Prevention of Witch-Hunting Bill, [www 03] (access: 9.06.2019). See also M. T. Iqbal, Witch Hunting: A Case of Gender Violence in the Garb of Vigilantism in India.

$3^{30}$ On RSS attempting to instill modernised forms of the "Great Tradition" in rural India, see P. Froerer, op. cit., pp. 115-144.

${ }^{31}$ See also L. Dumont op. cit., p. 403; A. Karp, Sanskrytyzacja, [in:] Religia. Encyklopedia PWN, [www 02] (access: 9.06.2019). 
played by initiatives of missionary work among tribal and untouchable communities, undertaken by the neo-Hindus and programmatically supported by Hindu nationalist groups.

15 Defence mechanisms, activated when Indian tribal communities came into contact with the representatives of the state - who would question the tribal rights to land, are so far poorly recognised. There are no historically attested, realistic testimonies about those encounters and the forms of opposition employed in the face of tribal land grab. ${ }^{32}$ Was defensive magic among them, was it resorted to?

Hindu mythology responded to the problem in its way. It created images of demons, monstrous opponents of the just, that is the dharmic state. Their brutal negation of the "universally accepted" rules - symbolically validated in a multitude of popular stories, their extermination as non-humans.

16 The compromises inherent in sanskritisation processes resulted in the manifestation of cultural parallelism specific to India. Its character reveals itself most clearly in the multiplicity of forms taken by religious life, actuated depending on the situation and the expectations connected with it. This is how the primitive type of religiosity, as presented by Presler, is brought back to life, first of all in ritual appeals directed towards the manifestations of personal and impersonal powers, and, also in the cultivation of such symbolic actions as exorcism and ecstatic dance. This belief complex assumes the presence of mediators - ritual specialists capable of controlling and manipulating manifestations of power. ${ }^{33}$

17 Both traditional medical systems, Hindu Ayurveda (āyurveda) and Muslim Unani $(y \bar{u} n \bar{a} n \bar{\imath})$ find themselves in decline, despite substantial state subsidies; more and more often, people who are after easy profit practice them. Western medicine - apart from the costs of treatment - still does not arouse trust because of the foreignness and often brutality of the healing procedures, and the specifically non-Indian idiom it uses (whiteness, impersonal

${ }^{32}$ The postulate to account in the research on the Indian tribal/rural witchcraft for its role as a social practice - expressed by S. Alam., A. Raj in their 2017 concise methodological study (The Academic fourney of Witchcraft Studies in India, p. 137).

${ }^{33}$ The most important among them are exorcist (h. jhär-phük karne vālā) and soothsayer (h. curail). 
spaces, the distance between the doctor and the patient, foreign terminology). Many patients turn to the least apparent alternative - to magical medicine. The treatment of a whole range of chronic diseases is increasingly entrusted to quacks and exorcists. The healing procedures used by them (rituals of reversing the disease or tying it up) can be effective only on the condition that both the patient and the physician participate in the same universe of symbols, signs and cultural references. ${ }^{34}$

This magical alternative is not limited only to health crises. Some of the procedures take the form of the group experience, such as in all-night vigils (h. jāgran, devī jāgraṇ), filled with collective singing, during which the goddess descends into the bodies of some of the participants of the rite, causing their temporary possession. It is a state in which it becomes possible for them to express the complaint on one's fate, to protest against the situation of handicap, social and familial. ${ }^{35}$

18 The worldview proposed by the manuals restores in the socially underprivileged, the untouchables and the tribals, a sense of participation, of the justified agency. Those who begin to perceive life as a game, whose participants are supported by non-human powers, can start fighting for themselves, to regain their subjectivity. Regardless of its evaluation, positive or negative, this is a worldview that adequately satisfies - to use the words of Andrzej Wierciński, from his 2010 book - "two typically human needs, the need for the meaning of life and the need for a generalised knowledge of the world." In the confrontation with all-pervasive violence, masked by slogans about constitutionally guaranteed equality of citizens, an entirely deliberate reaching for and use of magical procedures may be seen as a form of religious activity, that gives one the chance to regain a sense of dignity.

19 New media have revealed - probably to the surprise of many researchers of Hinduism - a thus far masked belief about the effectiveness of magic present among the representatives of Indian middle classes. Magic manuals appearing in print and as e-books have mostly been tailored to new standards. In northern India, many such publications no longer use the earlier, rough hindustān $\bar{l}$, they are arranged in pure Sanskritised Hindi (h. śuddh hindī). Spell formulas, although appealing to the power of the principal deities of

\footnotetext{
34 See V. Sujatha, op. cit., pp. 80-100.

35 On magical procedures and their media of expression, see S. J. Tambiah, op. cit.
} 
Hinduism (among them the goddess Kali), may outwardly resemble Vedic incantations. ${ }^{36}$

20 The popularity of manuals of magic proves that in the developing countries' conditions, rapid civilisational changes do not necessarily lead to either universal secularisation or the spread of "high" forms of religious life. On the contrary, these transformations seem to favour, in many cases, the disclosure of seemingly already rejected ideologies and images of the world.

The dynamics of these changes open the field for research on the renewal and further spread of the archaic, magical worldview - as one of the answers of Hinduism to the challenges of modernity.

\section{Bibliography}

1. Barrett R., Aghor Medicine. Pollution, Death, and Healing in Northern India, University of California Press, Berkeley 2008.

2. Bhattacharya N. N., Ancient Indian Rituals and Their Social Contents, Manohar, Delhi 1975.

3. Briggs G. W., The Chamārs, B. R. Publishing Corporation, Delhi 1975.

4. Chakravarty T., Medicalisation of Mental Disorder: Shifting Epistemologies and Beyond, "Sociological Bulletin" 6o (2/2011), pp. 266-286.

5. Crooke W., Religion \& Folklore of Northern India, Oxford University Press, Oxford 1926.

6. Dhru K. A., Acquisition of Land for 'Development' Projects in India: The Road Ahead, Research Foundation for Governance: in India, Ahmedabad 2010.

7. Dumont L., Homo Hierarchicus. The Caste System and Its Implications, Oxford University Press, Oxford 1970.

8. Froerer P., Religious Division and Social Conflict: The Emergence of Hindu Nationalism in Rural India, Social Science Press, New Delhi 2007.

9. Goudriann T., Gupta S., Māyā Divine and Human. A Study of Magic and Its Religious Foundations in Sanskrit Texts, with Particular Attention to a Fragment on Viṣnu's Māyā Preserved in Bali, Motilal Banarsidass, Delhi 1978.

${ }^{36}$ Emulating aggressive commercials of the newest technological fads, there appear on the TV and the net the advertisements of "businessmen of magic," who describe themselves as fully initiated heirs to ancient Vedic tradition, and offer their services at affordable prices. 
10. Goudriann T., Hindu Tantric Literature in Sanskrit, [in:] J. Gonda (ed.), Hindu Tantric and Śākta Literature (Vol. II, fasc. 2), Otto Harrassowitz Verlag, Wiesbaden 1981, pp. 1-162.

11. Harit H. L., Tribal Areas and Administration, [in:] R. S. Mann (ed.), Tribes of India: Ongoing Challenges, MD Publications PVT LTD, New Delhi 1996, pp. 49-54.

12. Hoernle R. A. F., The Bower Manuscript (Facsimile leaves, Nagari transcript, Romanised transliteration and English translation with notes), (reprint), Aditya Prakashan, Delhi 2011.

13. IQBAL M. T. Witch Hunting: A Case of Gender Violence in the Garb of Vigilantism in India, "International Journal of Advanced Research in Management and Social Sciences" 4 (11/2015), pp. 109-120.

14. KakAR S., Shamans, Mystics, and Doctors. A Psychological Inquiry into India and its Healing Traditions, Unwin Paperbacks, London 1984.

15. Karp A., Niedotykalni, [in:] T. Gadacz, B. Milerski (eds.), Religia. Encyklopedia PWN, vol. 7, Warszawa 2003, pp. 283-285.

16. KıоsкоwsкA A., Kultura masowa. Krytyka i obrona, PWN, Warszawa 2006.

17. Lorenzen D. N., Who Invented Hinduism, Yoda Press, New Delhi 2006.

18. MāKhandās M. Kh., Śrī cãvar purān tathā bhaktacetā (3rd Ed.), Śrī Loknāth Pustakālay, Kalkattā 2000.

19. Menta S., Tribal Situation in India. Encounters with Empiricism, [in:] R. S. Mann (ed.), Tribes of India: Ongoing Challenges, MD Publications PVT LTD, New Delhi 1996, pp. 55-56.

20. Mosse D., Caste and development: Contemporary perspectives on a structure of discrimination and advantage, "World Development" 110/2018, pp. $422-436$.

21. O'Flaherty W. Doniger, Women, Androgynes, and Other Mythical Beasts, University of Chicago Press, Chicago 1982.

22. Olivelle P., Dharmasūtras. The Law Codes of Āpastamba, Gautama, Baudhāyana, and Vāsiștha, Oxford World's Classics, Delhi 2000.

23. Olivelle P., King, Governance, and Law in Ancient India. Kautilya's Arthaśāstra, Oxford University Press, Oxford 2013.

24. O’Malley L. S. S., Popular Hinduism, The Religion of the Masses, Cambridge University Press, Cambridge 1935.

25. Presler H. H., Primitive Religions in India. A Textbook on the Primitive Religious Type Among India's Tribals, The Christian Literature Society Press, Bangalore 1971. 
26. Redfield R., Peasant Society and Culture, University of Chicago Press, Chicago 1956.

27. Saletore R. N., Indian Witchcraft. A Study in Indian Occultism, Abhinav Publications, New Delhi 1981.

28. SAPIR E., American Indians, [in:] D. G. Mandelbaum (ed.), Selected writings of Edward Sapir in Language, Culture, Personality, University of California Press, Berkeley 1949, pp. 387-487.

29. Singer M., When a Great Tradition Modernizes. An Anthropological Approach to Indian Civilization, Praeger Publishers, New York 1972.

30. Singh Y., Modernization of Indian Tradition: A Systematic Study of Social Change, Thomson Press, Delhi 1973.

31. Srinivas M. N., Social Change in Modern India, University of California Press, Berkeley 1966.

32. Stein R. L., Stein P. L., The Anthropology of Religion, Magic, and Witchcraft, Routledge, New York 2016.

33. Sujatha V., Food: The Immanent Cause from Outside - Medical Lore on Food and Health in Village Tamil Nadu, "Sociological Bulletin" 51 (1/2002), pp. 80-100.

34. Tambiah S. J., Magic, Science and Religion and the Scope of Rationality, Cambridge University Press 1990.

35. Thiagaraj H., Human Rights from the Dalit Perspective (2nd Rev. Ed.), Dalit Liberation Education Trust, Chennai 1998.

36. Unnithan T. K. N., Indra D., Singh Y., Towards a Sociology of Culture in India, [in:] T. K. N. Unnithan et al. (ed.), Towards a Sociology of Culture in India. Essays in Honour of Professor D. P. Mukherji, Prentice-Hall of India, New Delhi 1965, pp. 1-35.

37. White D. G., The Alchemical Body: Siddha Traditions in Medieval India, The University of Chicago Press, Chicago 1996.

38. Wierciński A., Magia i religia. Szkice z antropologii religii, 3rd Ed., Nomos, Kraków 2010.

\section{A selection of publications consulted but not directly quoted in the paper}

39. Choudhuri S., Tempest in a Teapot: Witches, Tea Plantations, and Lives of Migrant Laborers in India, Lexington Books, Lanham 2013.

40. Danielou A., Hindu Polytheism, Princeton University Press, Princeton 1964. 
41. Doniger W., On Hinduism, Oxford University Press, Oxford 2014.

42. Jurewicz J., Ciało boskie - ciało kosmiczne - ciało społeczne w myśli starożytnych Indii, [in:] K. Konarska (ed.), Colloquia Anthropologica et Communicativa: Ciato cielesne, Wydawnictwo Uniwersytetu Wrocławskiego, Wrocław 2011, pp. 45-59.

43. Ludden D., An Agrarian History of South Asia, Cambridge University Press, Cambridge 1999.

44. МсКім M., Village India: Studies in the Little Community, University of Chicago Press, Chicago 1969.

45. Sharma R. S., Material Culture and Social Formations in Ancient India, MacMillan Limited, Delhi 1983.

46. Sircar D. C., The Śäkta Pìthas (2nd Ed.), Motilal Banarsidass, Delhi 1973.

47. Timm J. R., Introduction: Texts in Context, [in:] J. Timm (ed.), Texts in Context. Traditional Hermeneutics in South Asia, Indian Books Centre, Delhi 1992, pp. 1-13.

48. Verardi G., The Gods \& The Heretics. Crisis and Ruin of Indian Buddhism. Aditya Prakashan \& Fundación Bodhiyāna, New Delhi - Buenos Aires 2018.

\section{Internet sources used}

[www 01] https://www.encyclopedia.com/international/encyclopediasalmanacs-transcripts-and-maps/scheduled-tribes

[www 02] https://www.academia.edu/35840542/sanskrytyzacja.pdf

[www 03] http://164.100.47.4/BillsTexts/LSBillTexts/AsIntroduced/4527LS.pdf [www 04] https://doi.org/10.1002/9781118924396.wbiea1915

[www 05] https://www.thecitizen.in/index.php/en/newsdetail/index/2/12386/ free-the-freedom-where-untouchability-is-locked-away-in-prisons 